\title{
Anti-edematous, anti-inflammatory and neuroprotective effect of etanercept in acute stage in experimental head injury
}

\author{
Ömer Aykanat, M.D., ${ }^{1}$ Durmuş Oğuz Karakoyun, M.D., ${ }^{1}$ Mehmet Erhan Türkoğlu, M.D., ${ }^{2}$ Cem Dinç, M.D. ${ }^{3}$
}

1'Department of Neurosurgery, Dr. Ersin Arslan Training and Research Hospital, Gaziantep-Turkey

${ }^{2}$ Department of Neurosurgery, Dışkapı Yıldırım Beyazıt Training and Research Hospital, Ankara-Turkey

${ }^{3}$ Department of Neurosurgery, Düzce University Faculty of Medicine, Düzce-Turkey

\begin{abstract}
BACKGROUND: To study the anti-edematous, anti-inflammatory, and neuroprotective effect of etanercept in the model of experimental head injury.

METHODS: In this study, 40 male-adult Spraque-Dawley rats, with weight ranging from $250 \mathrm{~g}$ to $300 \mathrm{~g}$, were used. The rats are divided into groups as control; non-penetrating trauma; trauma +NS; post-traumatic normal saline; trauma + D; post-traumatic dexamethasone and trauma + E. All medicines were given into peritoneum. After applying trauma and medicine, rats were decapitated in the $24^{\text {th }}$ hour and the samples were studied histopathologically.

RESULTS: In the study, a statistically significant difference was observed between the groups of trauma + NS and trauma dexamethasone according to the variables of edema and inflammation, but no difference was observed according to the variables of neuronal damage, astrocytic damage, and glial apoptosis. Moreover, a significant difference was observed between groups of Trauma + NS and trauma+etanercept and between the groups of trauma + dexamethasone and trauma + etanercept in terms of all variables.
\end{abstract}

CONCLUSION: It was observed that etanercept has anti-edematous, anti-inflammatory, and neuroprotective effect on the rats which experienced traumatic brain injury.

Keywords: Brain edema; etanercept; head injury.

\section{INTRODUCTION}

Head injury is one of the most commonly encountered problems in neurosurgery emergencies. Traumatic Brain Injury (TBI) occurring after head trauma continues to be a primary health problem despite all improvements in modern medicine. After trauma, primary brain injury occurs in central nerve system. Primary brain damage involves intracranial hemorrhage such as subdural hematoma, epidural hematoma, and intracerebral hematoma; skull fractures, scalp injury, brain contusion, and laceration. After head trauma, second-

Address for correspondence: Ömer Aykanat, M.D.

Binevler Mah., 52 Nolu Sok., No: 39/5, Şahinbey, Gaziantep, Turkey

Tel: +90 342 - 221 0700 E-mail: yomeycik@hotmail.com

Ulus Travma Acil Cerrahi Derg

2017;23(3): $173-180$

doi: $10.5505 /$ tjtes.2016.43692

Copyright 2017

TJTES ary damage as well as the primary damage is responsible for the injury occurring in the brain. The secondary damage is a situation depending on various physiopathological events and it could happen after hours or days from the primary brain damage. It has been proven that the secondary damage negatively influences the prognosis for the patients having TBI. Various mechanisms, such as neurotransmitter release, free radical formation, calcium dependent cell damage, gene activation, mitochondrial dysfunction, and inflammation, play role in the secondary damage. ${ }^{\left[{ }^{[]}\right]}$Besides, activation of excitatory receptors, hypermetabolism, ischemia, lack of membrane ion pumps, increase in arachidonic acid metabolism, cerebral edema, and acute brain swelling can also mediate secondary damage. ${ }^{[2]}$ The secondary brain injuries spread through neurochemical agents. ${ }^{[3]}$ Excitatory amino acids, such as glutamate and aspartate increase after TBI. They cause swelling in cells, vacuolization, and neuronal death. They not only lead to entry of chlorine and sodium into cells and thus causing acute neuronal swelling but also lead to delayed cell destruction depending on entry of calcium into cells. Increased metabolic activity in traumatized brain and decreased glucose 
consumption along with inducement of serotonergic system and post-traumatic sympatho-adreno medullary axis further increase the damage. To summarize, various pathophysiological mechanisms are responsible for brain deterioration function, e.g., increased release of neurotransmitters, including acetylcholine, catecholamine, and glutamate occurring immediately after the stroke. ${ }^{[4]}$ These are. Inflammation, which is responsible for the secondary damage, increases exitotoxity and intracranial pressure as a result of brain edema and unless effectively treated, it increases mortality and morbidity. For the treatment, commonly mannitol, hypertonic saline, hypothermia, barbiturate coma, and several anti-inflammatory drugs (TNF-alfa antagonists) are used. Some proinflammatory cytokines released after TBI cause microglial and astrocytic activation and this activation can increase the intensity of the damage. The leading proinflammatory cytokines are TNF-alpha, IL-I, and IL-6 which increase the severity of the damage by causing the secondary neuronal damage, destruction of the blood brain barrier, and cerebral edema. ${ }^{[5,6]}$

Etanercept is a dimer of a protein domain of recombinant TNF-alpha receptor that mediates its effect by binding to $\operatorname{lgGl}$. As it is an antagonist of TNF-Alpha, it shows a strong anti-inflammatory effect. In the previous studies, it that use of etanercept in the patients withTBI has been shown to reduce the dysfunction of blood brain barrier, intracerebral infiltration of neutrophils, and death of neuronal cell. As a result of these, it leads to significant recovery. ${ }^{[7]}$

Our aim in this study was to study the anti-edema, anti inflammatory and neuroprotective effects of etanercept in rats which underwent acute brain trauma.

\section{MATERIALS AND METHODS}

For this study, 40 male-adult Spraque-Dawley rats, weight ranging from $250 \mathrm{~g}$ to $300 \mathrm{~g}$ which have never participated in any test before, were used. The rats were procured from the Laboratory of Animal Studies and Production in Bolu Abant Izzet Baysal University. Until the experimental stage, they were fed with standard rat bait and tap water and kept in a cage for 12 hours night and 12 hours day time. During the whole experiment, standard conditions determined by the National Institute of Health in US were implemented. Induction of trauma and ongoing processes of the experiment were completed in the laboratory of Animal Studies and Production in Bolu Abant Izzet Baysal University. The ethical approval was obtained from the ethics committee of animal studies of Medical Faculty in Bolu Abant Izzet Baysal University on 13.02.2013 with 2012/62 code number.

\section{Groups}

Experiment animals were randomly divided into 4 groups, each of which has 10 rats.

Group I (Control group, C): No head trauma was applied to the rats in this group and they were not given any treatment.

Group 2 (Trauma+NS group, TP): Head trauma was applied to the rats in this group and then they were given NS.

Group 3 (Trauma+Dexamethasone group, TD): First, head trauma was induced in the rats in this group, then dexamethasone was given to them.

Group 4 (Trauma+Etanercept group, TE): Head trauma was induced in the rats in this group and etanercept was given to them afterwards.

\section{Anesthesia and Creating Trauma}

Before Anesthesia, all test subjects were weighed and they were given $50 \mathrm{mg} / \mathrm{kg}$ ketamine hydrochloride by intraperitoneal route. After checking anesthetic depth by corneal reflex and tail pinch test, the physiological values such as breathing, pulse, rectal temperature of the animals were recorded at $0^{\text {th }}$ and $24^{\text {th }}$ hour (Table I, 2).

The animals were weltered in the groups in which trauma was to be induced. A skin incision was made along the mid-line in a way in which bregma and lambdoid suture could be seen. Periosteum was separated from the edges so that sutures could be seen totally from the front to the back. A steel disc with diameter of $10 \mathrm{~mm}$ and thickness of $3 \mathrm{~mm}$ (Figure 3a ve 4a) was placed into the midline between coronal and lambdoid sutures. Subsequently, the rats were placed in prone position on a sponge ground measuring $12 \times 12 \times 43 \mathrm{~cm}$ and the trauma tool was positioned as described by Marmarou. A 450g steel bar targeting the animal's head was dropped from $2 \mathrm{~m}$ height through a tube, with $19 \mathrm{~mm}$ inside diameter and $25 \mathrm{~mm}$ outside diameter. Rats whose respiration was stopped soon after the trauma and whose pupils were dilated and who had seizure (respiratory arrest, 5 rats; seizure, 3 rats) were resuscitated by performing CPR. The resuscitation was continued until the sufficient respiration recovered. The skin incisions were sutured with $2 / 0$ silk suture. The animals whose respiration recovered were taken to their cages. Two rats killed during the trauma were replaced with the new ones, so the equal numbers in the groups were maintained. According to the treatment protocol in respective groups, the test subjects were given dexamethasone or etanercept via intraperitoneal route in various doses soon after the resuscitation. At $24^{\text {th }}$ hour, all animals were decapitated, their brain and brain stem were removed as a whole (Fig. I) and were fixed by $10 \%$ formalin.

\section{Histopathologic Assessment}

Brain materials, after fixation for 48 hours with $10 \%$ buffered formalin, were sliced in coronal plane, sampled as two from front to back and taken in tissue processing. Once they were dehydrated with the formalin, alcohol and xylene successively, paraffin blocks were prepared. After hydration and deparaf- 
Table I. BBetween-group distribution of physiological parameters measured before trauma (at 0th hour) of test subjects

\begin{tabular}{|c|c|c|c|c|}
\hline & $\begin{array}{l}\text { Control } \\
(n=10)\end{array}$ & $\begin{array}{c}\text { Trauma+NS } \\
(n=10)\end{array}$ & $\begin{array}{c}\text { Trauma+Dexamethasone } \\
\qquad(n=10)\end{array}$ & $\begin{array}{c}\text { Trauma+Etanercept } \\
(n=10)\end{array}$ \\
\hline & Mean $\pm S D$ & Mean $\pm S D$ & Mean士SD & Mean士SD \\
\hline Weight & $303.8 \pm 10.1$ & $307.5 \pm 8.1$ & $303.2 \pm 10.1$ & $302.4 \pm 7.9$ \\
\hline Rectal temperature & $36.2 \pm 0.2$ & $36.2 \pm 0.2$ & $36.4 \pm 0.2$ & $36.3 \pm 0.2$ \\
\hline Number of respirations & $130.8 \pm 0.9$ & $132.5 \pm 1.0$ & $134.3 \pm 1.1$ & $133.5 \pm 1.4$ \\
\hline Heart rate & $231.2 \pm 4.9$ & $233.4 \pm 6.1$ & $233.9 \pm 3.8$ & $235.4 \pm 5.2$ \\
\hline
\end{tabular}

NS: Normal Saline; SD: Standard deviation.

Table 2. Between-group distribution of physiological parameters measured after trauma (at $24^{\text {th }}$ hour) of the test subjects.

\begin{tabular}{|c|c|c|c|c|}
\hline & $\begin{array}{l}\text { Control } \\
(n=10)\end{array}$ & $\begin{array}{c}\text { Trauma+NS } \\
(n=10)\end{array}$ & $\begin{array}{l}\text { Trauma+Dexamethasone } \\
\qquad(n=10)\end{array}$ & $\begin{array}{l}\text { Trauma+Etanercept } \\
(\mathrm{n}=10)\end{array}$ \\
\hline & Mean士SD & Mean $\pm S D$ & Mean $\pm S D$ & Mean $\pm S D$ \\
\hline Weight & $301.3 \pm 9.9$ & $306.2 \pm 7.3$ & $302.8 \pm 5.9$ & $303.1 \pm 7.1$ \\
\hline Rectal temperature & $36.7 \pm 0.2$ & $36.1 \pm 0.2$ & $36.8 \pm 0.3$ & $36.3 \pm 0.1$ \\
\hline Number of respirations & $136.7 \pm 0.8$ & $134.3 \pm 0.7$ & $138.5 \pm 1.1$ & $137.7 \pm 1.2$ \\
\hline Heart rate & $240.4 \pm 6.1$ & $239.6 \pm 7.3$ & $242.1 \pm 4.3$ & $237.5 \pm 6.6$ \\
\hline
\end{tabular}

NS: Normal Saline; SD: Standard deviation.

finization, hematoxylin eosin stain and immunohisto-chemical stains such as anti caspase-3, anti IBA-I, anti GFAP, and anti NeuN were applied to $5 \mathrm{~mm}$ cross-sections taken from paraffin blocks, as the manufacturer states. The preparates studied by Nikon Eclipse $80 \mathrm{i}$ light microscope were transferred into the digital platform by Nikon DS-Fil camera attachment. In histopathological assessment, existence and severity of ede$\mathrm{ma}$, and existence and severity of inflammation were used as variables. The existence of edema was assessed according to occurrence of microcystic areas by opening inside of the cells in parenchyma, however, the severity of edema was assessed as $\mathrm{I}+$ when edema is less than $10 \%$ in a magnification of $20 x$ in microscope, $2+$ when it is between $10 \%$ and $50 \%$ and $3+$ when it is over $\% 50$. The existence of inflammation was conducted by searching the existence of leukocyte with polymorphic nuclei, lymphocyte, plasma cell and eosinophils.

\section{Immunohistochemical Assessment}

After the most affected sides in terms of cell damage were detected, preparates obtained as immunohistochemically were taken into the digital platform by taking view from the most effected sides three at a time during the large magnification (x200). The number of cytoplasmic cell GFAP, IBA, and Caspase 3 and the number of nuclear positive stained cell of NeuN was counted by means of digital program counter. In immunohistochemical assessment, astrocytes, microglial cells, severity and damage occurring in neurons, and severity and existence of glial apoptosis were taken as variables. The exis- tence of glial apoptosis was conducted by searching, with anti Caspase 3, the existence of glial cell that shows cytoplasmic positivity. The damage occurring in astrocytes was detected by searching, with anti GFAP (Glial fibrillary acidic protein), the existence of cell that shows cytoplasmic positivity. The damage occurring in microglial cells was detected by searching, with anti lba-I, existence of cell that shows cytoplasmic positivity while the damage occurring in neurons was detected by searching, with anti NeuN (Neuron-Specific Nuclear Protein), existence of cell that shows nuclear positivity. The severity of the occurring damage in cells was assessed as I+ when the number of cells that shows nuclear and cytoplasmic positivity was less than 10\%, 2+ when it was between $10 \%$ and $50 \%$, and $3+$ when it was over $\% 50$.

\section{Statistical Methods}

For the statistical comparison, chi-square tests ( $q$ square test) and SPSS 15.0 were used and $p$ value less than 0.05 was regarded as statically significant.

\section{Findings}

In the traumatic cases, in addition to edema and inflammation; microglial, astrocytic damage, and glial apoptosis were observed, however, in the dexamethasone group edema and inflammation decreased considerably and etanercept group all variables decreased significantly. The assessment of pathologies in different groups is shown in Table 3. 
While edema, inflammation, microglial cell damage, neuronal damage, astrocytic cell damage, and glial apoptosis was detected in rats in the control group (Fig. 2); edema and inflam- mation were detected at level $\mathrm{I}+$ in 10 rats in the normal saline group, 2+ microglial cell damage in 8 animals, 2+ neuronal and astrocytic damage in 7 animals and 2+ glial apoptosis in

Table 3. The table of pathological results

\begin{tabular}{|c|c|c|c|c|c|c|}
\hline Groups & Edema & Inflammation & Microglial damage & Astrocytic damage & Neuronal damage & Glial apoptosis \\
\hline C-I & - & - & - & - & - & - \\
\hline C -2 & - & - & - & - & - & - \\
\hline$C-3$ & - & - & - & - & - & - \\
\hline C -4 & - & - & - & - & - & - \\
\hline C -5 & - & - & - & - & - & - \\
\hline$C-6$ & - & - & - & - & - & - \\
\hline C -7 & - & - & - & - & - & - \\
\hline C -8 & - & - & - & - & - & - \\
\hline C -9 & - & - & - & - & - & - \\
\hline$C-10$ & - & - & - & - & - & - \\
\hline T+ NS-I & + & + & ++ & ++ & ++ & - \\
\hline$T+N S-2$ & + & + & - & ++ & ++ & ++ \\
\hline $\mathrm{T}+\mathrm{NS}-3$ & + & + & ++ & - & - & - \\
\hline $\mathrm{T}+\mathrm{NS}-4$ & + & + & ++ & ++ & ++ & - \\
\hline$T+N S-5$ & + & + & ++ & - & - & - \\
\hline$T+N S-6$ & + & + & - & ++ & ++ & ++ \\
\hline $\mathrm{T}+\mathrm{NS}-7$ & + & + & ++ & ++ & ++ & - \\
\hline $\mathrm{T}+\mathrm{NS}-8$ & + & + & ++ & ++ & ++ & - \\
\hline$T+N S-9$ & + & + & ++ & - & - & - \\
\hline$T+N S-10$ & + & + & ++ & ++ & ++ & ++ \\
\hline T+D-I & - & - & - & - & ++ & - \\
\hline$T+D-2$ & + & + & ++ & ++ & ++ & - \\
\hline$T+D-3$ & + & + & ++ & ++ & ++ & - \\
\hline$T+D-4$ & - & - & ++ & ++ & ++ & ++ \\
\hline$T+D-5$ & - & - & - & - & - & - \\
\hline$T+D-6$ & - & - & ++ & ++ & ++ & ++ \\
\hline T+D-7 & + & + & ++ & ++ & ++ & - \\
\hline$T+D-8$ & - & - & - & - & - & - \\
\hline$T+D-9$ & + & + & ++ & ++ & ++ & ++ \\
\hline$T+D-10$ & + & + & ++ & ++ & ++ & - \\
\hline $\mathrm{T}+\mathrm{E}-\mathrm{I}$ & - & - & - & - & - & - \\
\hline $\mathrm{T}+\mathrm{E}-2$ & - & - & + & + & + & + \\
\hline $\mathrm{T}+\mathrm{E}-3$ & - & - & - & - & - & - \\
\hline $\mathrm{T}+\mathrm{E}-4$ & + & + & + & + & - & - \\
\hline $\mathrm{T}+\mathrm{E}-5$ & - & - & - & - & - & - \\
\hline $\mathrm{T}+\mathrm{E}-6$ & - & - & - & - & - & - \\
\hline $\mathrm{T}+\mathrm{E}-7$ & - & - & + & + & + & + \\
\hline $\mathrm{T}+\mathrm{E}-8$ & - & - & - & - & - & - \\
\hline $\mathrm{T}+\mathrm{E}-9$ & - & - & - & - & - & - \\
\hline $\mathrm{T}+\mathrm{E}-10$ & - & - & - & - & - & - \\
\hline
\end{tabular}

C: Control; T + NS: Trauma + Normal Saline; T + D: Travma + Dexamethasone; T + E: Travma + Etanercept. 
3 animals (Fig. 3). In the dexamethasone group, edema and inflammation at I+ level was observed in all rats except 5 animals, 2+ microglial cell damage in 7 rats, 2+ neuronal damage in 8 rats, $2+$ astrocytic cell damage in 7 rats, and $2+$ glial apoptosis in 4 rats (Fig. 4).

In the etanercept group, edema and inflammation at I+ level was observed in I rat while 9 rats didn't show any edema and inflammation. Other histopathological changes include I+ microglial cell damage in 3 rats, I+ neuronal damage in I rat, I+ astrocytic cell damage in 3 rats, and I+ glial apoptosis in 2 rats (Fig. 5).

\section{RESULTS}

In our study, a statistically significant difference between the groups of trauma + dexamethasone and trauma + NS was observed according to the variables of edema and inflammation $(p=0.027)$, but there was no significant difference according to the variables of neuronal damage, astrocytic damage, and glial apoptosis $(p>0.05)$. A significant difference was observed between the groups of trauma + NS and trauma + etanercept in all variables $(p=0.003)$. Lastly, a significant difference was observed between the groups of trauma + dexamethasone and trauma + etanercept in the variables of edema and inflammation $(p=0.032)$, likewise, there was a significant difference in the variables of neuronal damage, astrocytic damage, and glial apoptosis $(p=0.004)$.

\section{DISCUSSION}

TBI is one of the most commonly encountered traumas which occurs depending on head injury and is a pathological situation that can be fatal or crippling and usually requires a prolonged treatment and care. However, physiopathological mechanism of secondary brain injury appearing within minutes or even days following the primary brain injury due to the trauma is not clearly known. In recent years, studies have focused on some cellular and biochemical factors. The

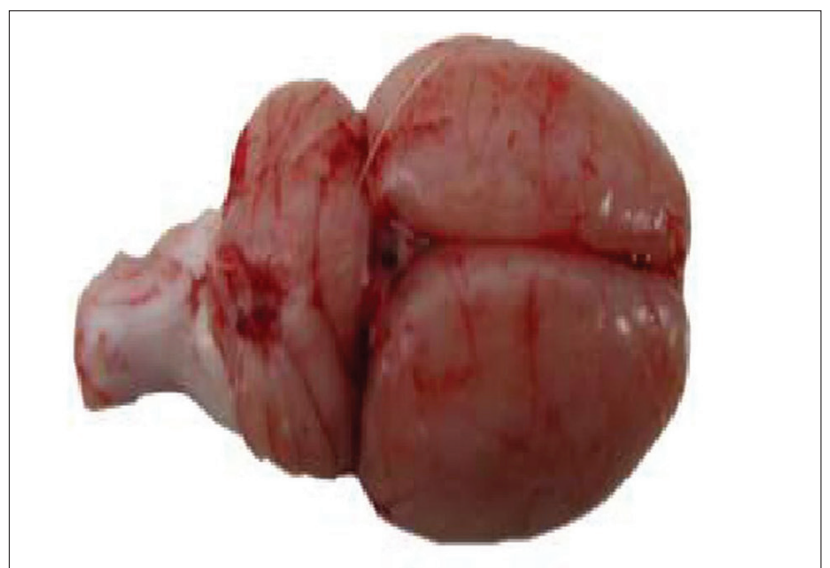

Figure 1. Tissue sample obtained after removing the brain and brain stem of the test subjects as a whole with decapitation. (from C group, Group-1). primary mechanisms causing the secondary injury include calcium dependent cell damage, neurotransmitter emission, free radical formation, gene activation, mitochondrial dysfunction, and inflammation. ${ }^{[]]}$Mortality and morbidity could be reduced with treatment by eliminating the factors causing secondary brain injury which significantly negatively affect the TBI prognosis. ${ }^{[8]}$

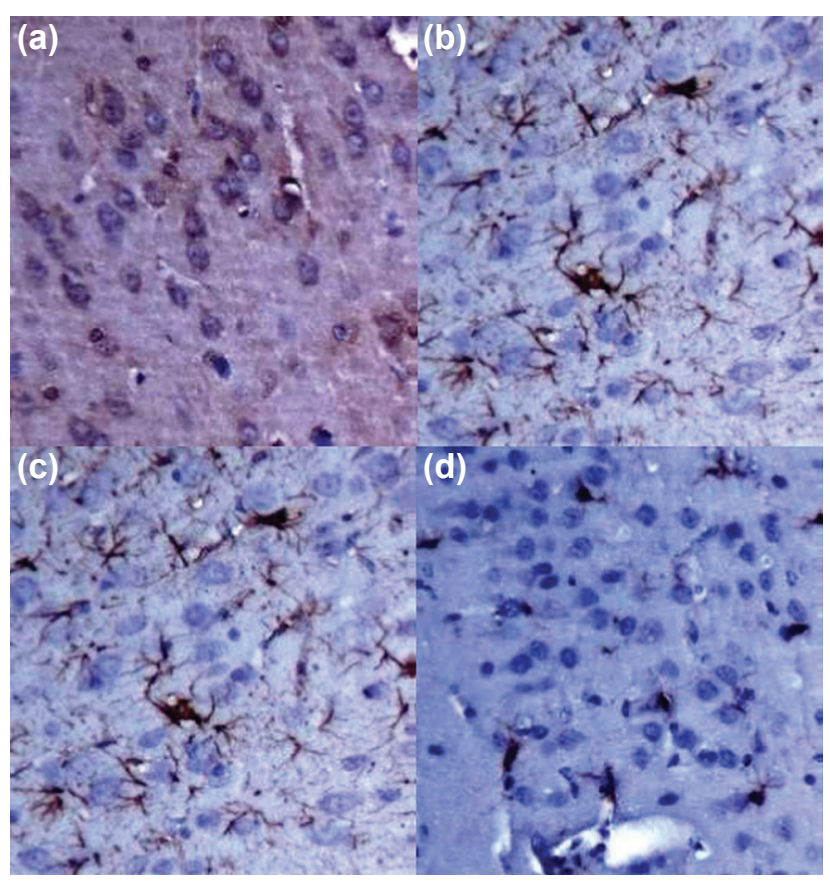

Figure 2. (a-d) The control group in which edema, inflammation, microglial cell damage, neuronal damage, astrocytic cell damage and glial apoptosis were not found.

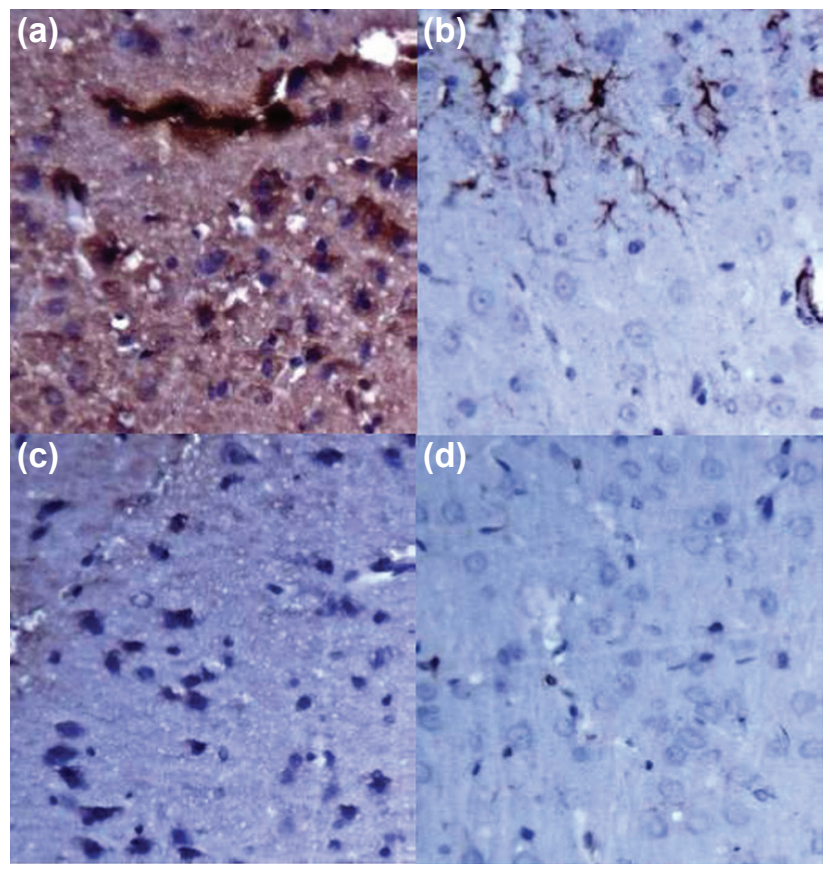

Figure 3. (a-d) Trauma + NS group in which edema, inflammation, microglial cell damage, neuronal damage, astrocytic cell damage and glial apoptosis were found. 


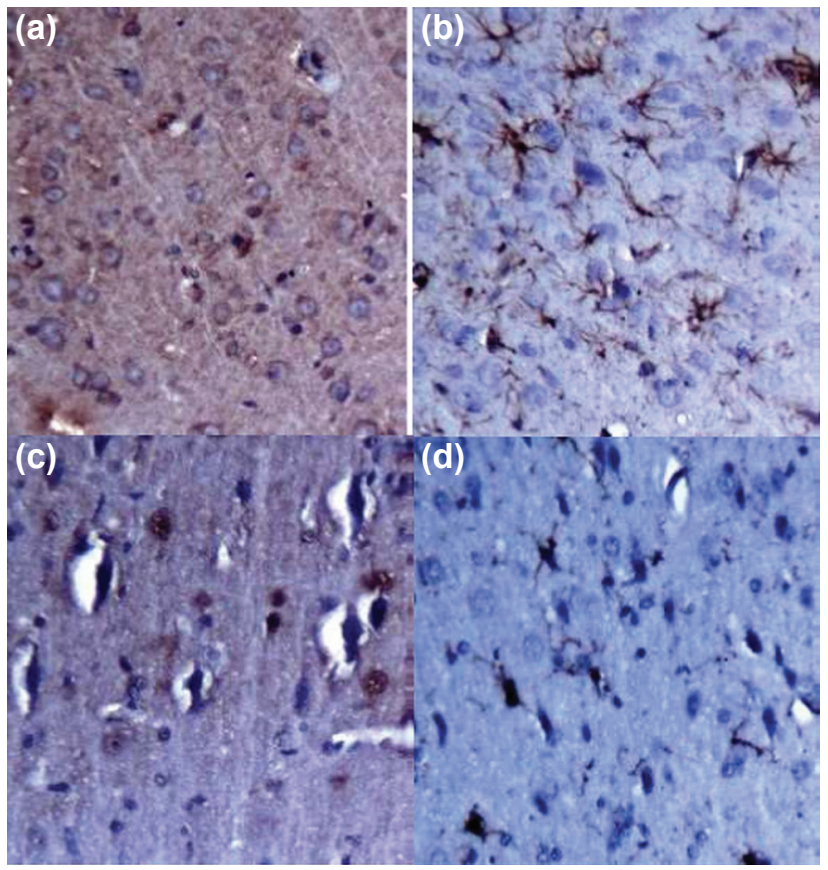

Figure 4. (a-d) The group given dexamethasone after trauma. It was observed that though edema and inflammation were seen, it was determined that there is no a specific change in microglial cell, neuronal, astrocytic cell damage and glial apoptosis.

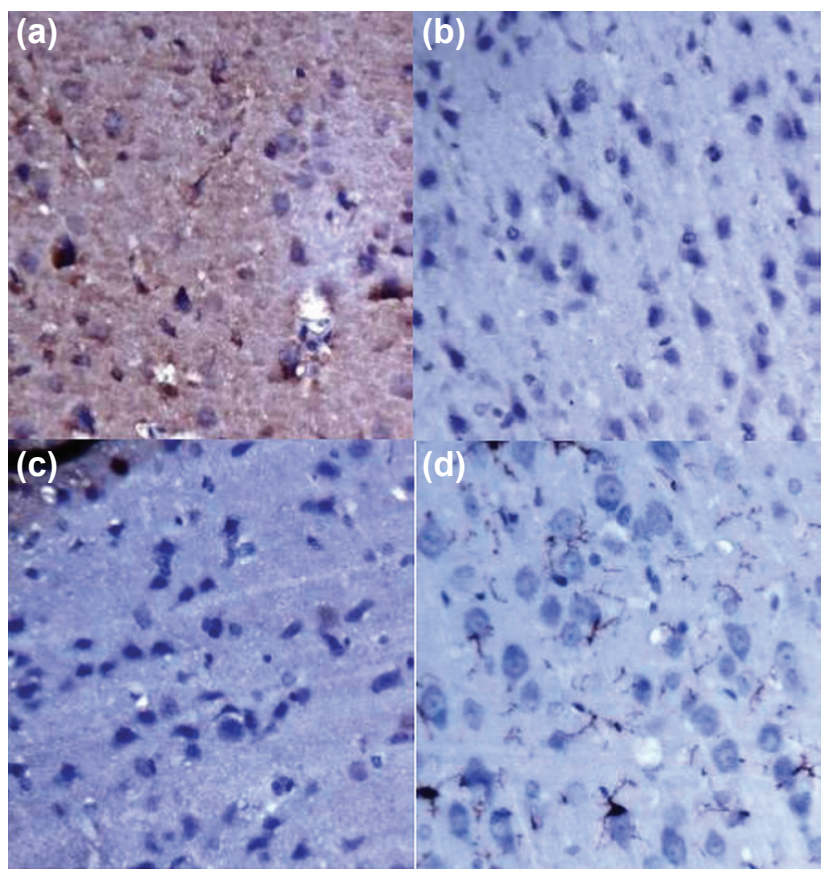

Figure 5. (a-d) The group given etanercept after trauma; it was observed that edema and inflammation were not seen, but microglial cell, neuronal cell, astrocytic cell damage and glial apoptosis decreased specifically.

In order to restrict the secondary biochemical damage and cell death in TBI, the effects of various pharmacological agents have been studied in various animal models. However, when these promising neuroprotective treatment protocols were applied to people, satisfactory success could not be obtained.
Some conceptual and methodological reasons increase the difficulties in transferring animal testing into clinics. ${ }^{[9]}$ Among the reasons, first is that there is little similarity between the traumatic brain injury in human and induced brain trauma in animal models, second, insufficient drug distribution and shortage or inappropriate time in animal testing could be attributed. Besides, the fact that these studies target on only one mechanism is perhaps the most important reason. ${ }^{[10]}$

In this study, etanercept treatment which is a TNF-alpha blocker in acute stage was given to the rats in which experimental head trauma was induced for studying the possible protective effects against the trauma-induced brain damage. On grounds of its similarity to diffuse head trauma seen in people and often occurring in motor vehicle crashes, a model of closed head injury in which the skull remains intact was practiced in this study as stated by Marmarou and Ark. ${ }^{\left[{ }^{11}\right]}$

Tumor Necrosis Factor Alpha (TNF $\alpha$ ) is called as cachectin and it is produced by many normal cells, tumor cells, and traumatic cells. It can also be produced by various stimulus such as viruses, bacteria, parasites, cytokines, and mitogens. In the solution, TNF $\alpha$ is a trimeric molecule which is both transmembrane and soluble. The secreted TNF $\alpha$ forms are biologically active. TNF-alfa is a cytokine the receptors of which have the capability to activate multiple signaling mechanisms due to their presence simultaneously in multiple locations and it has the capability to activate proinflammatory cytokines. In many studies conducted, it has been reported that TNF $\alpha$ plays an important role in TBI and leads to glial, microglial, astrocytic, and neuronal damage. ${ }^{[12-16]} \mathrm{TBI}$ is related with microglial and astrocytic cell activation, and the secretion of proinflammatory cytokines like TNF $\alpha$ and IL-I. [17] TNF $\alpha$ which is secreted after trauma and which is one of major proinflammatory cytokines of trauma plays an important role in inducing brain edema and neuronal cell damage, and in breaking down of blood brain barrier. Therefore, it is important to understand basic mechanism of TNF $\alpha$ levels and the consequences which increased after trauma. ${ }^{[6]}$ It has been reported that TNF $\alpha$ causes extensive calcium build-up in cell and this triggers the process resulting in free radical formation and lipid peroxidation and at the same time it leads to calmodulin dependent nitric oxide synthase activity making up toxic hydroxyl radicals and hampering mitochondrial respiration. ${ }^{[16]}$ Rising of intracellular calcium causes the break-down of oxidative phosphorylation, the formation of free radicals, the increasing of cellular enzymes, and death by dissolving of cell metabolism. ${ }^{[18]}$

Etanercept is a recombinant TNF $\alpha$ antagonist which is effective when it binds TNF-alpha receptor proteins on IgG. Due to the antagonistic effect, it displays a strong anti inflammatory effect. It is preferred as a primary cure for many rheumatic diseases. The experimental studies in recent years have shown that etanercept could be beneficial in TBI. Etanercept cannot cross CSF due to its high molecular weight. However, 
since blood brain barrier is broken down in TBI, it crosses CSF and it can display protective effect on glial cells, neurons, and microglial cells, and anti-inflammatory and anti-edema effect on cerebral tissue. ${ }^{[19]}$ In some studies, it was reported that etanercept prevents leukocytes infiltration to protect brain and spinal cord from secondary damage, thereby inhibiting the inflammatory reaction of brain. ${ }^{[20,21]}$

In the research, it has been shown that in traumatic brain edema, vasogenic edema resulting from blood-brain barriers disruption is not the only reason of clinical deterioration, cellular edema associated with ischemia is also involved. ${ }^{[12]}$ Increased secretion of proinflammatory cytokines like TNFalpha causes the imbalance of sodium and calcium, and this leads to ischemic edema. ${ }^{[22-25]}$ In a previous study on focal cerebral ischemia/reperfusion by Yoo-kyung Kim et al., central cerebral artery occlusion was done and after 24 hours reperfusion was enabled. Etanercept $5 \mathrm{mg} / \mathrm{kg}$ via intraperitoneal route was given 20 minutes before occlusion. Consequently, it has been proved that etanercept attenuates brain edema and infarct in all groups and it has neuroprotective effect. ${ }^{[16]}$ In their study on neuroprotective effect of etanercept in spinal cord injury in rats, Ke-Bing Chen et al. exhibited with histopathological and biochemical parameters that etanercept has anti-inflammatory and anti-apoptotic effect, besides it has neuroprotective effect on neurons and oligodendroglias. They suggested that etanercept could be used as a neuroprotective agent in spinal cord injury. ${ }^{[17,18]}$

In our study, for edema and inflammatory variables, a statistically significant difference $(p=0.027)$ between the groups of trauma+NS and trauma+dexamethasone was observed, whereas there was no significant difference $(p>0.05)$ in terms of neuronal damage, astrocytic damage, and glial apoptosis variables. In terms of all variables, there was a significant difference $(p=0.003)$ between the groups of trauma+NS and trauma+etanercept. On the other hand, the significant difference $(p=0.032)$ was observed between the groups of trauma+dexamethasone and trauma+etanercept for edema and inflammatory variables and $(p=0.004)$ for neuronal damage, astrocytic damage, and glial apoptosis variables. Edema and inflammation was seen in all 10 rats in trauma+NS group, in 5 rats in trauma+dexamethasone group and in only I rat in trauma+etanercept group; neuronal and astrocytic damage was seen in 7 rats in trauma+NS group; in trauma+dexamethasone group, neuronal damage was seen in 8 rats and astrocytic damage in 7 rats; in trauma+etanercept group, neuronal and astrocytic damage were seen in 2 rats. In addition, 2+ glial apoptosis in 3 rats in trauma+NS group, $2+$ glial apoptosis in 4 rats in trauma+dexamethasone group and I+ glial apoptosis in 2 rats in trauma+etanercept group were observed. This shows that both dexamethasone and etanercept have anti-inflammatory and anti-edema effect and anti inflammatory and anti-edema effects with latter showing stronger effects than former. It also shows that etanercept has neuroprotective effect.

\section{Conclusion}

Our study results have shown that etanercept has anti-inflammatory, anti-edema, and neuroprotective effects in acute traumatic brain injury and it can be protective against traumatic brain injury. We are of the opinion that for the treatment of traumatic brain injury, etanercept could be a beneficial option for people.

\section{Conflict of interest: None declared.}

\section{REFERENCES}

1. Maas AI, Stocchetti N, Bullock R. Moderate and severe traumatic brain injury in adults. Lancet Neurol 2008;7:728-41. [CrossRef]

2. Greenberg MS: Handbook of Neurosurgery. Thieme New York 2001:677-79.

3. Lloyd DA, Carty H, Patterson M, Butcher CK, Roe D. Predictive value of skull radiography for intracranial injury in children with blunt head injury. Lancet 1997;349:821-4. [CrossRef]

4. Meyer P, Legros C, Orliaguet G. Critical care management of neurotrauma in children: new trends and perspectives. Childs Nerv Syst 1999;15:732-9. [CrossRef]

5. Lucas S. M, Rothwell N. J, Gibson R. M. The role of inflammation in CNS injury disease. Br. J. Pharmacol 2006;147:232-40. [CrossRef]

6. Hailer NP, Vogt C, Korf HW, Dehghani F. Interleukin-1beta exacerbates and interleukin-1 receptor antagonist attenuates neuronal injury and microglial activation after excitotoxic damage in organotypic hippocampal slice cultures. Eur J Neurosci 2005;21:2347-60. [CrossRef]

7. Stahel PF, Shohami E, Younis FM, Kariya K, Otto VI, Lenzlinger PM, et al. Experimental closed head injury: analysis of neurological outcome, blood-brain barrier dysfunction, intracranial neutrophil infiltration, and neuronal cell death in mice deficient in genes for pro-inflammatory cytokines. J Cereb Blood Flow Metab 2000;20:369-80. [CrossRef]

8. Yi JH, Hazell AS. Excitotoxic mechanisms and the role of astrocytic glutamate transporters in traumatic brain injury. Neurochem Int 2006;48:394-403. [CrossRef]

9. Faden AI, Stoica B. Neuroprotection: challenges and opportunities. Arch Neurol 2007;64:794-800. [CrossRef]

10. Leker RR, Shohami E. Cerebral ischemia and trauma-different etiologies yet similar mechanisms: neuroprotective opportunities. Brain Res Brain Res Rev 2002;39:55-73. [CrossRef]

11. Marmarou A, Foda MA, van den Brink W, Campbell J, Kita H, Demetriadou K. A new model of diffuse brain injury in rats. Part I: Pathophysiology and biomechanics. J Neurosurg 1994;80:291-300. [CrossRef]

12. Adén U, Favrais G, Plaisant F, Winerdal M, Felderhoff-Mueser U, Lampa J, et al. Systemic inflammation sensitizes the neonatal brain to excitotoxicity through a pro-/anti-inflammatory imbalance: key role of TNFalpha pathway and protection by etanercept. Brain Behav Immun 2010;24:747-58.

13. Ekdahl CT, Claasen JH, Bonde S, Kokaia Z, Lindvall O. Inflammation is detrimental for neurogenesis in adult brain. Proc Natl Acad Sci U S A 2003;100:13632-7. [CrossRef]

14. Jiang Y, Deacon R, Anthony DC, Campbell SJ. Inhibition of peripheral TNF can block the malaise associated with CNS inflammatory diseases. Neurobiol Dis 2008;32:125-32. [CrossRef]

15. Kato K, Liu H, Kikuchi S, Myers RR, Shubayev VI. Immediate anti-tumor necrosis factor-alpha (etanercept) therapy enhances axonal regeneration after sciatic nerve crush. J Neurosci Res 2010;88:360-8. [CrossRef]

16. Knoblach SM, Fan L, Faden AI. Early neuronal expression of tumor necrosis factor-alpha after experimental brain injury contributes to neurological impairment. J Neuroimmunol 1999;95:115-25. [CrossRef]

17. Rostworowski M, Balasingam V, Chabot S, Owens T, Yong VW. As- 
trogliosis in the neonatal and adult murine brain post-trauma: elevation of inflammatory cytokines and the lack of requirement for endogenous interferon-gamma. J Neurosci 1997;17:3664-74.

18. Feuerstein GZ, Liu T, Barone FC. Cytokines, inflammation, and brain injury: role of tumor necrosis factor-alpha. Cerebrovasc Brain Metab Rev 1994;6:341-60.

19. Francis J, Chu Y, Johnson AK, Weiss RM, Felder RB. Acute myocardial infarction induces hypothalamic cytokine synthesis. Am J Physiol Heart Circ Physiol 2004;286:H2264-71. [CrossRef]

20. Campbell SJ, Jiang Y, Davis AE, Farrands R, Holbrook J, Leppert D, et al. Immunomodulatory effects of etanercept in a model of brain injury act through attenuation of the acute-phase response. J Neurochem 2007;103:2245-55. [CrossRef]

21. Genovese T, Mazzon E, Crisafulli C, Di Paola R, Muià C, Bramanti P, et al. Immunomodulatory effects of etanercept in an experimental model of spinal cord injury. J Pharmacol Exp Ther 2006;316:1006-16. [CrossRef]

22. Katayama Y, Becker DP, Tamura T, Hovda DA. Massive increases in extracellular potassium and the indiscriminate release of glutamate following concussive brain injury. J Neurosurg 1990;73:889-900. [CrossRef]

23. Kontos HA. Oxygen radicals in CNS damage. Chem Biol Interact 1989;72:229-55. [CrossRef]

24. Laura D. Errante \& Ognen A. C. Petroff. Acute effects of gabapentin and pregabalin on rat forebrain cellular GABA, glutamate, and glutamine concentrations. Seizure 2003;12:300-6. [CrossRef]

25. Chen KB, Uchida K, Nakajima H, Yayama T, Hirai T, Watanabe S, et al. Tumor necrosis factor- $\alpha$ antagonist reduces apoptosis of neurons and oligodendroglia in rat spinal cord injury. Spine (Phila Pa 1976) 2011;36:1350-8. [CrossRef]

\section{DENEYSEL ÇALIŞMA - ÖZET}

\section{Deneysel kafa travmasında etanercept'in akut dönemdeki anti-ödem, anti-enflamatuvar ve nöroprotektif etkisi \\ Dr. Ömer Aykanat, ${ }^{1}$ Dr. Durmuş Oğuz Karakoyun, ${ }^{1}$ Dr. Mehmet Erhan Türkoğlu, ${ }^{2}$ Dr. Cem Dinç}

${ }^{1}$ Dr. Ersin Arslan Eğitim ve Araştırma Hastanesi, Beyin ve Sinir Cerrahisi Kliniği, Gaziantep

${ }^{2}$ Dışkapı Yıldırım Beyazıt Eğitim ve Araştırma Hastanesi, Beyin ve Sinir Cerrahisi Kliniği, Ankara

${ }^{3}$ Düzce Üniversitesi Tıp Fakültesi, Beyin ve Sinir Cerrahisi Anabilim Dalı, Düzce

AMAÇ: Deneysel kafa travması modelinde etanerceptin antiödem, antienflamatuvar ve nöroprotektif etkinliğinin araştııılması amaçlandı.

GEREÇ VE YÖNTEM: Bu çalışmada ağııııları 250-300 g arasında değişen 40 adet erkek erişkin Spraque-Dawley sıçanı kullanıldı. Sıçanlar kontrol; travma uygulanmayan; travma+SF; travma sonrası serum fizyolojik, travma+D; travma sonrası deksametazon ve tarvma+E: travma sonrası etanercept verilen gruplara ayrıldı. Tüm ilaçlar periton içine verildi. Travma ve ilaç uygulaması sonrası 24. saatte sıçanlar dekapite edildi, örnekler histopatolojik olarak incelendi.

BULGULAR: Çalışmamızda ödem ve enflamasyon değişkenlerine göre travma+SF ve travma+deksametazon grupları arasında istatistiksel olarak anlamlı bir farklılık tespit edildi, nöronal hasar, astrositik hasar ve glial apoptoz değişkenlerine göre ise anlamı bir farklılık tespit edilmedi. Travma+SF ile travma+etanercept grupları arasında ve travma+deksametazon ile travma+etanercept grupları arasında tüm değişkenlere göre istatistiksel olarak anlamlı bir farkllık izlendi.

TARTIŞMA: Travma sonrası beyin hasarı oluşturulan sıçanlarda etanercept uygulamasının antiödem, antienflamatuvar ve nöroprotektif etkisinin olduğu saptanmıştır.

Anahtar sözcükler: Beyin ödemi; etanercept; kafa travması.

Ulus Travma Acil Cerrahi Derg 2017;23(3):173-180 doi: 10.5505/tjtes.2016.43692 